\title{
ANALISIS FAKTOR FAKTOR YANG MEMPENGARUHI PERILAKU BELANJA ONLINE MAHASISWA YANG BERDOMISILI DI KABUPATEN SLEMAN
}

\author{
Youngky Dian Andhika Putra \\ Sekolah Tinggi Ilmu Manajemen YKPN Yogyakarta \\ Email: youngkydian66@gmail.com \\ Any Agus Kana \\ Sekolah Tinggi Ilmu Manajemen YKPN Yogyakarta \\ Email: aguskanaany@gmail.com
}

\begin{abstract}
Abstrak
Penelitian ini bertujuan untuk mengetahui pengaruh manfaat, risiko, motivasi hedonis, psikologis dan desain situs terhadap perilaku belanja online mahasiswa yang berdomisili di Kabupaten Sleman. Responden sebanyak 130 orang merupakan mahasiswa yang kuliah di Yogyakarta berdomisili di 14 kecamatan di Sleman. Sampel diambil dengan teknik non probability sampling menggunakan metode purposive sampling, yaitu mahasiswa yang pernah melakukan pembelian online karena jika belum pernah, maka dimungkinkan belum bisa merasakan pengaruh faktor faktor tersebut. Pengumpulan data dilakukan dengan menggunakan kuesioner, berupa 26 pernyataan. Setelah dilakukan uji instrumen, uji asumsi dasar dan uji asumsi klasik, maka diketahui bahwa semua variabel /item pernyataan diketahui dapat digunakan untuk penelitian.

Berdasar hasil uji t dan uji regresi linear berganda ditemukan bahwa manfaat, risiko, motivasi hedonis, psikologis dan desain situs berpengaruh positif dan signifikan terhadap perilaku belanja online mahasiswa yang berdomosili Kabupaten Sleman.
\end{abstract}

Kata kunci: manfaat, risiko, motivasi hedonis, psikologis, desain situs dan perilaku belanja online.

\begin{abstract}
This study aims to determine the effect of benefit, risk, hedonic motivation, psychologic factor, web design on online shopping behavior of higher students.130 respondents were higher students who lived in 14 kecamatan in Sleman Regency. Sample were taken by non probability sampling techniques using purposive sampling method, namely students who have had once shopped on online shopping, because if they had not shopped yet online shopping they had not experience. Data collection is done using a questionnaire. After testing the instrument, testing the basic asumption, and testing the clasiccal asumptions, it is item statements are known to be used for research. Based on the results of the t test and multiple regression tests, it was found that benefit, risks, hedonic motivation, pshychology factors and web design had a positif and significant effect on online shopping behavior of higher students who lived in Sleman Regency.
\end{abstract}

Keywords: benefits, risk, hedonic motivation, psychological factors, web design, online shopping behavior

\section{PENDAHULUAN}

Internet telah mengubah cara bisnis di seluruh dunia dan melahirkan e-business. E-business adalah istilah yang digunakan untuk menggambarkan bisnis yang dijalankan pada internet atau penggunaan internet untuk meningkatkan produktivitas dan keuntungan bisnis (McGuigan, 2003). Ecommerce merupakan salah satu aplikasi penerapan dari kegiatan e-business. E-commerce merupakan penggunaan teknologi informasi yang dapat meningkatkan hubungan antara perusahaan dengan pelanggannya yang digunakan untuk penyebaran, pembelian, penjualan, pemasaran barang, dan jasa melalui sistem elektronik seperti internet atau televisi, www, atau jaringan komputer lainnya (Sutabri, 2012). Penggunaan teknologi informasi pada E-commerce membentuk hubungan dalam ekonomi baru diantaranya seperti B2C (Business to Customer) dan $\mathrm{C} 2 \mathrm{C}$ (Customer to Customer). Baik B2C maupun $\mathrm{C} 2 \mathrm{C}$ memunculkan perilaku belanja online yang berbeda dengan belanjan offline (konvensional). 
Clcose dan Kukar-Kinney (2010) menjelaskan bahwa perilaku belanja online biasanya menunjukkan aktivitas pembelian barang atau jasa di internet. Belanja online telah mengalami perubahan karena kemudahan, kenyamanan, hemat biaya, hemat waktu dan pengiriman yang lebih cepat dibandingkan dengan belanja konvensional atau tradisional. Kegiatan belanja online yang terus meningkatnya mendorong perusahaan untuk mengembangkan cara mereka menawarkan produk pada layanan online. Hal tersebut disadari perusahaan membantu meningkatkan daya saing di e-commerce.

Keberadaan e-commerce telah menjadi fenomena global. Robinson (2010) menemukan Inggris adalah pasar terbesar $e$-commerce pada tahun 2010. Di China $e$-commerce juga berkembang. Berdasarkan data menunjukkan penjualan online di China pada tahun 2009 mencapai 36.6 miliar dolar Amerika (Olsen, 2010). Negara lain seperti Korea Selatan, Jepang, Brasil, Perancis, Jerman, dan Rusia juga menunjukkan perkembangan dari e-commerce dari tahun ke tahun.

Berikut ini adalah Gambar 1.1 yang menujukkan pertumbuhan B2C (Business To Consumers) E-Commerce beberapa Negara di dunia.

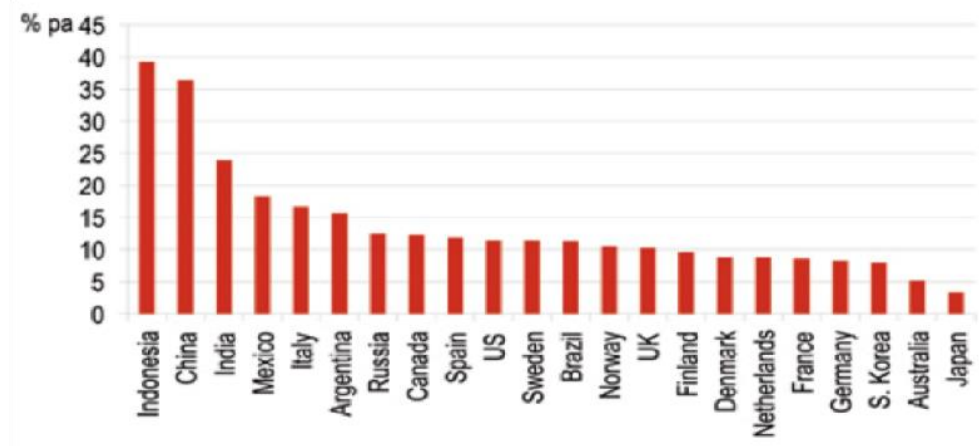

Gambar 1.

Pertumbuhan B2C E-Commerce di beberapa Negara 2013-2017

Sumber: Global E-Commerce and Retail Logistic, 2013.

Data dari Jones Lang Lasalle (2014) memprediksi pertumbuhan B2C E-Commerce Indonesia akan terus meningkat hingga mencapai hampir $40 \%$ dibandingkan dengan China, India bahkan Amerika sekalipun.

Kemendag sangat mendukung usaha perdagangan melalui online atau dikenal dengan $e$ commerce, dari angka Rp 34,9 triliun pada 2015, diprediksikan akan meningkat menjadi Rp 224,9 triliun pada tahun 2016 (Goenawan, 2015). Di Yogyakarta pengguna e-commerce ataupun belanja online cukup besar, hal ini terlihat dari data yang menunjukkan bahwa 72\% atau senilai Rp 29,9 miliar pendapatan Kantor Pos Besar Yogyakarta (PT Pos Indonesia) berasal dari pengiriman bisnis online (jogja.tribunnews.com).

Kim, Lee dan Kim (2004) menemukan bahwa meskipun penjualan online telah mencapai puncaknya dalam beberapa tahun terakhir, ada bukti yang menunjukkan fenomena penjual ditinggalkan atau produk yang ditawarkan penjual tidak lagi dibeli. Sekitar $82 \%$ dari pembeli pengguna internet yang berpengalaman meninggalkan situs belanja online tanpa menyelesaikan transaksi mereka karena masalah konten dari situs yang kurang memadai (Kearney, 2001). Rheman (2000) menunjukkan sekitar $43 \%$ dari upaya pembelian gagal karena konten dari website yang kurang memadai.

Adnan (2014) menunjukkan bahwa upaya pembelian konsumen seringkali gagal karena mereka tidak dapat menemukan produk yang tepat atau mereka tidak dapat menyelesaikan transaksi online, atau mereka meragukan kredibilitas dari prosedur pembayaran. Dengan demikian, perilaku belanja online secara langsung dipengaruhi oleh pengalaman yang dirasakan sebelumnya. Selain faktor internal, faktor eksternal juga berpengaruh.

Faktor eksternal antara lain dari penyedia layanan belanja online. Faktor eksternal tersebut mempengaruhi unsur-unsur psikologis seperti kepercayaan dalam belanja online, manfaat yang dirasakan dan risiko serta pengalaman belanja online sebelumnya dari pengguna layanan belanja online.

Adanya gap hasil penelitian terdahulu dan belum banyaknya penelitian yang mengambil subyek mahasiswa, maka penelitian ini dilakukan. Berdasarkan fenomena di atas maka penelitian ini bertujuan untuk: (1) menganalisis pengaruh manfaat terhadap perilaku belanja online pada mahasiswa 
yang berdomisili di Sleman, (2) menganalisis pengaruh risiko terhadap perilaku belanja online pada mahasiswa yang berdomisili di Sleman, (3) menganalisis pengaruh motivasi hedonis terhadap perilaku belanja online pada mahasiswa yang berdomisili di Sleman, (4) menganalisis pengaruh faktor psikologis terhadap perilaku belanja online pada mahasiswa yang berdomisili di Sleman, (5) menganalisis pengaruh desain situs terhadap perilaku belanja online pada mahasiswa yang berdomisili di Sleman dan (6) menganalisis pengaruh manfaat, risiko, motivasi hedonis, faktor psikologis, dan desain situs pada perilaku belanja online pada mahasiswa yang berdomisili di Sleman. Dengan demikian diharapkan dapat memberikan manfaat bagi perusahaan yang melakukan bisnis online untuk memperhatikan faktor-faktor yang mempengaruhi perilaku belanja online mahasiswa.

\section{TINJAUAN PUSTAKA}

\section{Pengertian Pemasaran}

Teknologi informasi telah mengubah struktur organisasi bisnis dan secara radikal mengubah cara pekerja dan pelanggan saling berhubungan (Ebert dan Griffin, 2017). Iklan dilihat dengan media telepon seluler, iPads, laptop, PDAs, tablet dan smartphone dan kita mengakses Internet setiap hari. Pemakaian teknologi informasi yang intens dan masif memaksa pelaku bisnis untuk melakukan perubahan pada cara berbisnis. Salah satu yang diubah adalah pemasarannya dalam upaya meningkatkan penjualan dan juga memahami apa yang diharapkan oleh pelanggan yang memiliki mindset baru.

Menurut Abdullah (2012), pemasaran adalah kegiatan kreasi dan realisasi sebuah standar hidup. Kegiatan pemasaran meliputi menyelidiki dan mengetahui apa yang diinginkan konsumen, kemudian merencanakan dan mengembangkan sebuah produk untuk memenuhi kebutuhan tersebut, selanjutnya memutuskan cara terbaik untuk menentukan harga, promosi, dan mendistribusikan produk tersebut. Menurut Kotler dan Armstrong (2012), pemasaran adalah proses dimana perusahaan menciptakan nilai bagi pelanggan dan membangun hubungan serta nilai yang kuat dengan pelanggan dengan tujuan untuk mendapatkan nilai pengembalian dari pelanggan.

\section{E-Commerce}

Penggunaan teknologi informasi dalam operasi bisnis khususnya pemasaran telah mengubah bentuk hubungan antara perusahaan dengan pelanggannya. Sutabri (2012) menjelaskan bentuk hubungan dalam ekonomi baru yang terbentuk diantaranya seperti B2C (Business to Customer) dan C2C (Customer to Customer).

E-Commerce menurut Wong (2010) adalah pembelian, penjualan dan pemasaran barang serta jasa melalui sistem elektronik, seperti televisi, radio dan jaringan komputer atau internet. Ebert dan Griffin (2017) mengatakan e-commerce adalah pemakaian Internet dan alat elektronik lain untuk transaksi penjualan eceran dan Business to Business (B2B) dan menciptakan new market relationships di seluruh dunia. E-Commerce memakai sebuah Web site untuk bertransaksi atau memfasilitasi penjualan produk secara online. Para pedagang online (online retailers) telah dapat diramalkan menyediakan kemudahan, informatif, pengalaman personal untuk konsumen dan bisnis yang sangat berbeda. Pedagang online bersaing di tiga aspek transaksi, yakni: 1) interaksi pelanggan dengan Web site, 2) pengiriman dan, 3) kemampuan untuk menyelesaikan problem jika terjadi (Kotler dan Keller, 2012). Syarat tersebut untuk memudahkan pelanggan dalam melakukan belanja online (online shopping).

Perusahaan yang mempraktikkan E-Commerce harus men set-up dan mengoperasikan Web site secara sangat hati-hati. Customer service merupakan hal kritis, Web site harus cepat, simpel dan mudah diakses. Sejumlah survai pelanggan menemukan bahwa yang menghalangi online shopping adalah tidak adanya pengalaman yang menyenangkan, interaksi sosial dan konsultasi personal dengan perwakilan perusahaan (Kotler dan Keller, 2012). E-Commerce memiliki beberapa manfaat, baik untuk konsumen, organisasi, perusahaan maupun masyarakat itu sendiri (Suyanto, 2003).

\section{Belanja online dan Belanja onffline}

Belanja online dalam e-commerce adalah sebuah perkembangan dari belanja offline (konvensional). Dalam belanja offline konsumen harus bertemu langsung dengan penjual dari barang atau jasa yang ditawarkan. Sedangkan dalam belanja online memungkinkan konsumen untuk langsung membeli barang atau jasa dengan menggunakan jaringan internet melalui toko online tanpa harus bertatap muka langsung dengan penjual. 
Belanja online sama halnya dengan berbelanja dipasar tradisional atau modern yang ada di dunia nyata namun yang membedakan pada cara bertransaksi atau proses jual belinya dengan menggunakan jaringan internet dan pada perilaku konsumen yang terbentuk di dalamnya (Pratiwi, 2013). Perilaku konsumen adalah studi bagaimana individu, kelompok dan organisasi memilih, membeli, menggunakan dan menempatkan barang, jasa, ide atau pengalaman untuk memuaskan keinginan dan kebutuhan mereka (Kotler dan Keller, 2012)\. Perilaku konsumen dalam belanja online adalah tindakan-tindakan yang dilakukan oleh konsumen baik individu, kelompok maupun organisasi yang berhubungan ataupun mempengaruhi proses pengambilan keputusan dalam mendapatkan barang secara online (Suhari, 2011). Menurut Shahzad (2015) online shopping behavior adalah suatu persepsi menyeluruh dan evaluasi dari pelanggan atas produk atau jasa selama proses belanja online yang bisa menghasilkan kesimpulan baik atau buruk. Adnan (2014) menjelaskan terdapat lima faktor yang mempengaruhi konsumen dalam pengambilan keputusan ketika melakukan belanja online yaitu manfaat, risiko, motivasi hedonis, faktor psikologis, dan desain situs.

\section{Manfaat}

Soopramanien dan Robertson (2007) menunjukkan kemudahan dan penghematan waktu adalah alasan utama yang memotivasi konsumen untuk melakukan belanja online. Schaupp dan Bélanger (2005) berpendapat bahwa e-commerce telah mengurangi usaha dan menghemat waktu dalam menemukan pedagang. Hal tersebut membuktikan bahwa manfaat yang dirasakan dari belanja online secara signifikan akan berdampak pada perilaku konsumen dalam melakukan transaksi.

\section{Risiko}

Adnan (2014) menjelaskan konsumen juga mempertimbangkan risiko terkait dengan transaksi yang akan dilakukan. Risiko ini dapat mencakup keamanan, keuangan dan risiko privasi. Oleh karena itu, risiko yang akan dihadapi berdampak pada perilaku konsumen ketika melakukan belanja online. Chen, Hsu, dan Lin (2010) berpendapat bahwa dampak risiko keamanan pada belanja online mengacu pada kemungkinan adanya kerugian keuangan terhadap konsumen.

Javadi, dkk (2012) menemukan bahwa variabel seperti risiko keuangan dan risiko non-pengiriman memiliki dampak negatif secara langsung pada perilaku belanja online dari konsumen.

\section{Motivasi Hedonis}

Motivasi Hedonis pada belanja online mengacu pada kenikmatan, dan kenyamanan serta kegunaan yang dirasakan oleh pembeli ketika menggunakan jasa belanja online (Prihandy dan Hatammimi, 2014). Kim, Lee, dan Kim (2004) menyelidiki faktor yang mempengaruhi pencarian dan niat belanja online konsumen dan hasil dari penelitian tersebut menunjukkan bahwa faktor-faktor seperti nilai manfaat dan nilai hedonis pada informasi belanja online, dan pengalaman adalah faktor utama niat pencarian yang dilakukan konsumen pada belanja online.

\section{Faktor Psikologis}

Titchener (1921) menjelaskan faktor psikologis adalah merupakan pikiran, perasaan, dan perilaku individu yang dipengaruhi oleh kehadiran orang lain atau lingkungan secara aktual, dibayangkan, atau hadir secara tidak langsung yang pada akhirnya mempengaruhi individu tersebut dalam melakukan sebuah perilaku.

Faktor psikologis seperti masalah privasi dan masalah keamanan dapat mempengaruhi perilaku dari pembeli dalam melakukan belanja online. Lee dan Huddleston (2010) berpendapat risiko privasi dan masalah keamanan terkait dengan kekhawatiran karena konsumen harus mengungkapkan informasi pribadi mereka saat berbelanja online dapat menjadi salah satu faktor yang mempengaruhi perilaku belanja online.

\section{Desain Situs}

Ali (2010) menjelaskan desain situs sangat berpengaruh kepada penilaian pengunjung akan bagus tidaknya sebuah situs. Desain situs pada dasarnya adalah menampilan informasi menggunakan media internet berupa teks, gambar, suara maupun video yang interaktif baik yang bersifat statis maupun dinamis tanpa mengurangi estetika mudah digunakan dan dipahami oleh pengguna situs (Ali, 2010).

Chen, Hsu dan Lin (2010) menemukan bahwa fitur yang mudah dipahami dan desain yang menarik dari situs belanja online mempengaruhi pengambilan keputusan yang dilakukan oleh pembeli. 


\section{Pengembangan Hipotesis}

\section{Hubungan manfaat dengan perilaku belanja online}

Internet menjadi media yang sangat populer untuk memfasilitasi pencarian informasi, memilih dan membeli (Forsythe et all, 2006). Tingkat perubahan penggunaan Internet untuk media belanja semakin tinggi. Para shoppers menggunakan Internet untuk media belanja karena adanya sejumlah manfaat yang diperoleh. Personalitas setiap konsumen adalah berbeda, hal tersebut dapat mempengaruhi persepsi dan bagaimana perasaan mereka atas manfaat belanja online. Dalam konteks belanja online, manfaat yang dirasakan konsumen adalah kelebihan atau kepuasan atas permintaan mereka (Delafrooz.,et.all., 2010). Menurut Delafrooz et.all. (2010) manfaat antara lain: kemudahan dalam berbelanja, kemudahan mencari informasi, informasi harga yang menarik, ketersediaan produk yang dapat dipilih, hemat waktu, biaya murah dan layanan pelanggan. Manfaat ini didirasakan oleh personalitas yang berorientasi pada utilitarian.

Pendapat tersebut terbukti dalam penelitian yang dilakukan oleh Prihandy dan Hattamimii (2015) dengan subyek konsumen umum di wilayah JABODETABEK, yang menyatakan bahwa variabel manfaat berpengaruh signifikan terhadap perilaku belanja online. Temuan yang sama dilakukan oleh Hsu (2012) dengan subyek para konsumer online store yang diambil secara random dari www.tedy.mn online store in Mongolian menyatakan bahwa manfaat sangat menentukan perilaku belanja online. Berdasarkan hal tersebut, maka hipotesis yang dipaparkan dalam penelitian ini adalah:

$\mathrm{H}_{1}$ : Manfaat berpengaruh positif terhadap perilaku belanja online mahasiswa yang berdomisili di Kabupaten Sleman.

\section{Hubungan risiko dengan perilaku belanja online}

Disrupsi teknologi telah mengubah cara berbisnis termasuk cara konsumen berbelanja (Khasali 2017). Belanja online tidak disangkal telah memberikan manfaat yang sangat banyak bagi konsumen, produsen, retailer dan pihak lain terkait. Belanja online seperti keping mata uang yang punya dua sisi, selain memberikan manfaat juga mendatangkan risiko. Sejumlah peneliti telah mengidentifikasi bermacam-macam risiko terkait dengan perilaku belanja online. Penelitian Lee, Park dan Ahn (2001) mengidentifikasi risiko keuangan yang dikaitkan dengan hilangnya uang akibat transaksi. Penelitian Forsythe et all, (2006) mengidentifikasi risiko terkait dengan kinerja produk dan waktu yang hilang dalam proses pembelian dan penerimaan produk. Penelitian Bhatnagar et al (2000) risiko terkait dengan keamanan kartu kredit dan informasi pribadi. Risiko-risiko tersebut muncul dalam proses belanja online yang dialami oleh shoppers.

Pendapat tersebut terbukti dalam penelitian yang dilakukan oleh Prihandy dan Hattamimii (2015) dengan subyek konsumen umum di wilayah JABODETABEK, yang menyatakan bahwa variabel manfaat berpengaruh signifikan terhadap perilaku belanja online. Temuan yang sama dilakukan Wani dan Malik (2013) dengan subyek para shoppers dari India dan United Kingdom (UK) dengan kriteria mereka telah memakai internet selama lebih dari 5 tahun. Hasilnya menyatakan bahwa risiko berpengaruh terhadap perilaku belanja online namun berbeda antara shoppers India dan UK. Berdasarkan hal tersebut, maka hipotesis yang dipaparkan dalam penelitian ini adalah:

$\mathrm{H}_{2}$ : Risiko berpengaruh positif terhadap perilaku belanja online mahasiswa yang berdomisili di Kabupaten Sleman.

\section{Hubungan motivasi hedonis dengan perilaku belanja online}

Adanya peningkatan yang cepat populasi belanja online maka total jumlah konsumsi online juga tumbuh secara dramatis. Batra dan Ahtola (1991) menyatakan bahwa kepuasan konsumsi tidak hanya berasal dari produk yang dibeli tetapi juga dari imbalan-imbalan emosional personal selama proses belanja. Makin banyak pelanggan yang melihat belanja sebagai alat untuk mencari kesenangan, fantasi, kegembiraan, dan pengalaman yang menyenangkan baik dalam lingkungan belanja offline maupun online (Lai To dan Sung, 2014). Hal-hal tersebut merupakan elemen dari motivasi hedonis. Childer et al (2001) yakin bahwa belanja online akan meningkat jika para pengecer online dapat menciptakan lingkungan belanja yang interaktif dan menghibur untuk memuaskan kebutuhan emosi shoppers.

Pendapat tersebut terbukti dalam penelitian yang dilakukan oleh Prihandy dan Hattamimii (2015) dengan subyek konsumen umum di wilayah JABODETABEK, yang menyatakan bahwa variabel motivasi hedonis berpengaruh signifikan terhadap perilaku belanja online. Penelitian yang dilakukan oleh Lai-To dan Sung (2014) dengan tehnik focus group discusion mencakup 36 shoppers terpilih yang mempunyai pengalaman belanja online menemukan bahwa motivasi hedonis menentukan perilaku belanja online. Berdasarkan hal tersebut, maka hipotesis yang dipaparkan dalam penelitian ini adalah: 
$\mathrm{H}_{3}$ : Motivasi hedonis berpengaruh positif terhadap perilaku belanja online mahasiswa yang berdomisili di Kabupaten Sleman.

\section{Hubungan faktor psikhologis dengan perilaku belanja online}

Faktor psikhologis dalam konteks penelitian ini lebih ditekankan pada pada kepercayaan (trust) dan keamanan (security). Kepercayaan dan keamanan atas proses belanja online sangat diperlukan karena tanpa keduanya transaksi tidak akan terjadi. Shoppers lebih memilih belanja offline karena ada kepastian (certainty) dalam hal misalnya barang sudah ada dan pasti sama dengan yang dibutuhkan, tidak ada waktu tunggu, jumlah uang yang dibayar pasti, tidak ada informasi yang hilang atau diminta oleh penjual. Menurut Ariff et al (2013) faktor psikhologis mencakup kepercayaan dan keamanan terkait dengan tingkat proteksi yang disediakan oleh website dan perlindungan atas keamanan data personal pelanggan. Roman (2007) menyatakan bahwa faktor keamanan mengindikasikan keyakinan belanja online juga mengkait keamanan informasi keuangan pelanggan tidak boleh dibagi dengan pihak lain.

Pendapat tersebut terbukti dalam penelitian yang dilakukan oleh Prihandy dan Hattamimii (2015) dengan subyek konsumen umum di wilayah JABODETABEK, yang menyatakan bahwa variabel faktor psikhologis berpengaruh signifikan terhadap perilaku belanja online. Studi Yoruk et al (2011) terhadap perilaku belanja online Turki dan Rumania menemukan bahwa dalam lingkungan belanja online, kepercayaan dan keamanan merupakan faktor penghalang utama bagi konsumen melakukan belanja online. Menurut penelitian Monsuwe et al (2004) retailer yang menjaga kepercayaan dan keamanan informasi personal memberi dorongan positif shopper untuk melakukan belanja online. Berdasarkan hal tersebut, maka hipotesis yang dipaparkan dalam penelitian ini adalah:

$\mathrm{H}_{4}$ : Faktor psikhologis berpengaruh positif terhadap perilaku belanja online mahasiswa yang berdomisili di Kabupaten Sleman.

\section{Hubungan desain situs dengan perilaku belanja online}

Banyaknya situs belanja online tidak mnjamin bahwa shopper bersedia melakukan melanjtkan transaksinya. Ada sejumlah shopper yang sengaja membatalkan transaksinya karena alasan: sulit mengakses, butuh waktu lama prosesnya, tidak ada ruang untuk konsultasi bila ada masalah, prosedur tidak jelas bahkan tidak ada. Menurut Li dan Zhang (2002) mutu desain situs dapat diidentifikasi antara lain dari: konten informasi website, presentasi informasi, interaksi antara pelanggan dan perusahaan, navigasi, mekanisme pencarian, keamanan, technical feature, media richness. Ringkasnya dapat dikatakan bahwa faktor yang terkait dengan mutu desain situs mempengaruhi perilaku konsumen dalam melakukan belanja online.

Pendapat tersebut terbukti dalam penelitian yang dilakukan oleh Prihandy dan Hattamimii (2015) dengan subyek konsumen umum di wilayah JABODETABEK, yang menyatakan bahwa variabel desain situs berpengaruh signifikan terhadap perilaku belanja online. Penelitian yang dilakukan Suwunniponth (2014) kepada 350 responden yang mempunyai pengalaman melakukan belanja online di Bangkok menyatakan bahwa desain situs berpengaruh terhadap perilaku belanja online. Berdasarkan hal tersebut, maka hipotesis yang dipaparkan dalam penelitian ini adalah:

$\mathrm{H}_{5}$ : Desain situs berpengaruh positif terhadap perilaku belanja online mahasiswa yang berdomisili di Kabupaten Sleman.

\section{Hubungan manfaat, risiko, motivasi hedonis, faktor psikhologis dan desain situs terhadap perilaku belanja online mahasiswa}

Perilaku belanja online diantaranya dipengaruhi oleh fakter internal dan eksternal. Faktor internal merupakan faktor yang berasal dari diri shopper seperti manfaat, risiko, motivasi hedonis, budaya, nilai-nilai, dan faktor psikhologis. Faktor eksternal adalah faktor yang berasal dari luar diri shopper, antara lain desain situs, kinerja produk, sistem pembayaran dan, pengiriman barang. Dengan demikian perilaku belanja onlinediantaranya dipengaruhi oleh manfaat, risiko, motivasi hedonis, faktor psikhologis dan desain situs. Secara parsial masing-masing faktor telah dihepotesiskan mempengaruhi perilaku belanja online, maka hipotesis keenam dirumuskan sebagai berikut:

$\mathrm{H}_{6}$ : Manfaat, risiko, motivasi hedonis, faktor psikhologis dan desain situs signifikan terhadap perilaku belanja online mahasiswa yang berdomisili di Kabupaten Sleman 
Berikut adalah kerangka pemikiran yang diajukan dalam penelitian ini:

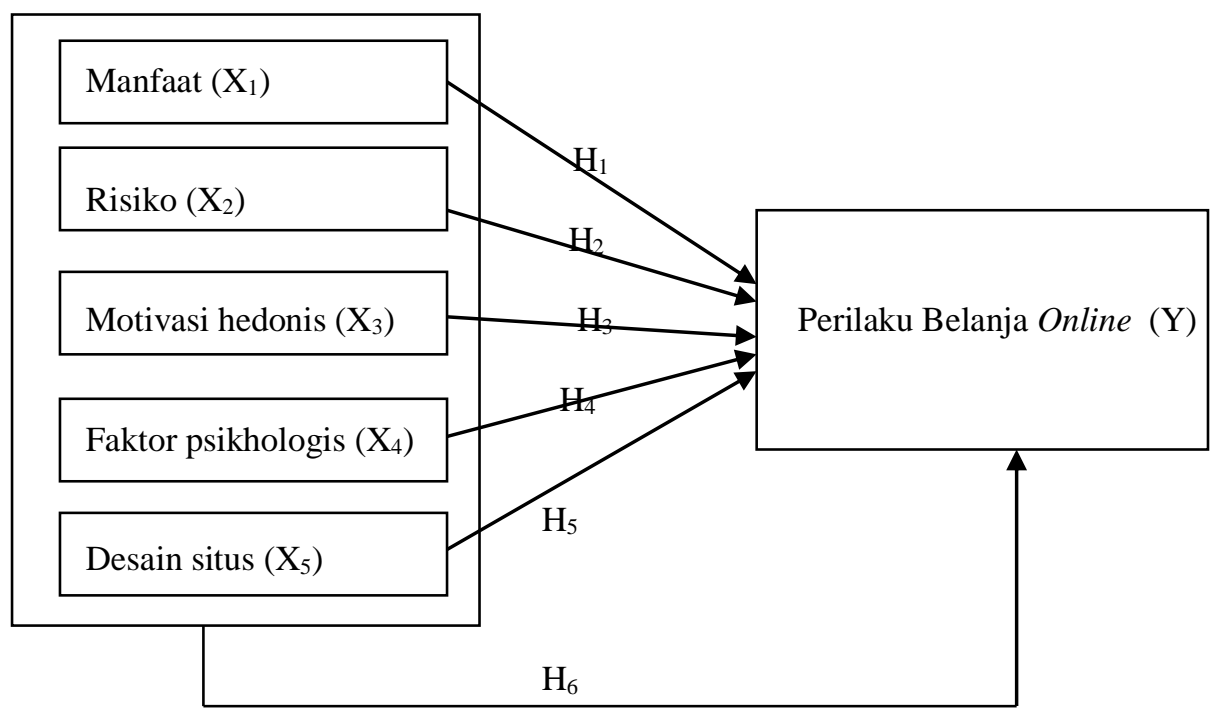

Gambar 2.

Kerangka Pemikiran

\section{METODE PENELITIAN}

\section{Definisi Operasional}

\section{Variabel bebas (Independent variables)}

Menurut Wiyono (2011) variabel independen adalah variabel yang mempengaruhi atau menjadi penyebab terjadinya perubahan terhadap variabel dependen. Dalam penelitian ini yang termasuk variabel independen disimbolkan dalam huruf $\mathrm{x}$, adalah sebagai berikut:

a. Manfaat $\left(\mathrm{X}_{1}\right)$

Menurut Forsythe et al., (2006) manfaat merupakan persepsi subyektif konsumen mengenai hasil (gain) dari belanja online. Manfaat dapat diukur dengan indikator sebagai berikut:

1. Kemudahan (convenience) dalam berbelanja

2. Pilihan produk dan informasi produk secara detail

3. Tidak memerlukan interaksi langsung, prosedur transaksi dijelaskan .

b. Risiko $\left(\mathrm{X}_{2}\right)$

Menurut Forsythe et al., (2006) risiko merupakan kecenderungan untuk menghadapi ketidak pastian terkait dengan proses pembelian. Risiko yang dihadapi meliputi 3 (tiga) jenis yakni: risiko kinerja produk, risiko keuangan dan risiko waktu (kemudahan). Risiko dapat diukur dengan indikator sebagai berikut:

1. Mendapatkan barang yang tidak sesuai dengan harapan

2. Adanya kesulitan ketika melakukan pengembalian barang karena tidak sesuai

3. Risiko tidak menerima barang yang telah dibeli

4. Risiko dikenakan biaya tambahan untuk pengiriman barang.

c. Motivasi Hedonis $\left(\mathrm{X}_{3}\right)$

Menurut Forsythe et al., (2006) motivasi hedonis merupakan dorongan yang muncul dari dalam diri konsumen untuk melakukan belanja online dengan gembira dan ketertarikan karena adanya pengalaman baru custom designing product, dan lain lain. Risiko dapat diukur dengan indikator sebagai berikut:

1. Memilih menghabiskan waktu untuk berbelanja online

2. Adanya anggapan bahwa berbelanja online adalah hal yang menyenangkan.

d. Faktor Psikologis $\left(\mathrm{X}_{4}\right)$

Menurut Khanh dan Gim (2014) faktor psikhologis diidentikan dengan ketidak-percayaan. Faktor psikhologis mempengaruhi keputusan konsumen apakah memilih berbelanja secara online atau offline. Ketidak-percayaan mencakup dua hal yakni keamanan (security) dan privacy. Ketidakpercayaan dapat diukur dengan indikator sebagai berikut:

1. Kepercayaan dalam berbelanja onlilne 
2. Keamanan dalam berbelanja online.

e. Desain Situs $\left(\mathrm{X}_{5}\right)$

User menilai desain situs/web design dari mutunya. Menurut Adnan (2014), mutu desain situs/web design merupakan dapat diukur dengan indikator sebagai berikut:

1. Estetika dan konten yang terdapat dalam situs

2. Kemudahan dalam mengakses situs belanja online

3. Desain transaksi

\section{Variabel Terikat (Dependent Variable)}

Menurut Wiyono (2011) variebel dependen adalah variabel yang dipengaruhi oleh variebel independen. Dalam

dalam penelitian ini variabel dependen adalah perilaku belanja online mahasiswa. Menurut Suhari (2011), perilaku belanja online dapat diukur dengan indikator:

a. Kemudahan dalam belanja online

b. Pendapat dari kerabat dan keluarga

c. Keamanan dalam belanja online

d. Konektivitas yang cepat dari situs belanja online

\section{Metode Pengambilan Sampel}

Populasi dalam penelitian ini adalah mahasiswa yang berdomisili di Sleman, dan pernah melakukan kegiatan belanja online. Dalam penelitian ini peneliti tidak bisa memperoleh jumlah mahasiswa yang berdomisili di Sleman secara pasti, maka digunakan sampel. Pengambilan sampel dilakukan dengan menggunakan non probability sampling. Metode yang dipakai adalah Purposive Sampling. Menurut Sugiyono (2013) Purposive Sampling merupakan tehnik penentuan sampel dengan pertimbangan tertentu. Pada penelitian ini sampel yang diambil adalah mahasiswa di Yogyakarta yang berdomisili Sleman dan pernah melakukan belanja online.

Banyaknya sampel yang diambil didasarkan pada pendapat rumus Hair et al. (1998) dalam buku Multivariate Data Analysis yang dikutip Husein Umar (2008) dalam Wiyono 2011) yag menyatakan bahwa jumlah sampel ditentukan dengan mengalikan 5x jumlah item pertanyaan/pernyataan. Penelitian ini menggunakan 26 item pernyataan, maka sampel yang digunakan sebanyak 130 responden.

\section{Metode Pengambilan Data}

Data diambil dengan menggunakan kuesioner dengan skala Likert. Pengukuran setiap instrumen pernyataan menggunakan skala likert dari sangat setuju (skor nilai 5) sampai dengan sangat tidak setuju (skor nilai 1).

\section{Metode Analisis Data}

Metode analsisi dalam penelitian meliputi uji instrumen (validitas dan reliabilitas), uji asumsi dasar (normalitas), uji asumsi klasik (multikolinearitas dan heteroskedastisitas), dan uji hipotesis. Untuk mengetahui arah hubungan antara variabel independen dengan variabel dependen, digunakan uji regresi linear berganda. Adapun persamaannya adalah sebagai berikut:

$Y=\alpha+\beta_{1} X_{1}+\beta_{2} X_{2}+\beta_{3} X_{3}+\beta_{4} X_{4}+\beta_{5} X_{5}+e$

$\mathrm{Y}=$ Perilaku Belanja Online

$\alpha=$ Konstanta

$\mathrm{X}_{1}=$ Manfaat

$\mathrm{X}_{2} \quad$ = Risiko

$\mathrm{X}_{3}=$ Motivasi Hedonis

$\mathrm{X}_{4}=$ Faktor Psikologis

$\mathrm{X}_{5}=$ Desain Situs

$\beta_{1} \quad=$ Koefisien regresi untuk variabel Manfaat

$\beta_{2} \quad=$ Koefisien regresi untuk variabel Risiko

$\beta_{3}=$ Koefisien regresi untuk variabel Motivasi Hedonis

$\beta_{4}=$ Koefisien regresi untuk variabel Faktor Psikologis

$\beta_{5} \quad=$ Koefisien regresi untuk variabel Desain Situs

$\mathrm{e}=$ error term/ standar error

Untuk mengetahui ada tidaknya pengaruh variabel independen terhadap variabel dependen secara parsial digunakan uji t dengan $\alpha=0,05$. Sedangkan untuk mengetahui ada tidaknya pengaruh variabel 
independen terhadap variabel dependen secara simultan digunakan uji F. Koeffisien determinasi $\left(\mathrm{R}^{2}\right)$ untuk menunjukkan seberapa besar persentase keragaman variabel dependen yang dapat dijelaskan oleh keragaman variabel independen (Sugiyono, 2013). Nilai $\mathrm{R}^{2}$ yang kecil berarti kemampuan variabel independen dalam menjelaskan variasi variabel dependen yang amat terbatas. Nilai $\mathrm{R}^{2}$ yang mendekati satu berarti variabel independen memberikan hampir semua informasi yang dibutuhkan untuk memprediksi variasi variabel dependen. Menurut Ghozali (2016), secara umum koeffisien determinasi untuk data silang relatif rendah karena adanya variasi yang besar antara masing-masing pengamatan. Pada penelitian ini digunakan Ajusted $R^{2}$ karena nilai Ajusted $R^{2}$ dapat naik atau turun apabila satu variabel independen ditambahkan ke dalam model (Ghozali, 2016).

\section{HASIL DAN PEMBAHASAN}

Dalam pengumpulan data peneliti mendistribusikan kuesioner kepada 130 responden. Semua responden mengembalikan kuesioner secara lengkap. Penelitian ini merupakan penelitian yang menggunakan data primer, yaitu data yang diperoleh dari penyebaran kuesioner. Data penelitian ini adalah data silang (crossection). Pengolahan data dalam penelitian ini menggunakan SPSS 19.00 for Windows. Hasil uji intrumen, uji asumsi dasar, uji asumsi klasik menunjukkan bahwa semua instrumen dan semua variabel layak digunakan untuk digunakan dalam penelitian.

130 responden berasal dari 14 kecamatan di kabupaten Sleman dengan komposisi sebagai berikut: Minggir (2\%), Seyegan (2\%), Godean (2\%), Gamping (2\%), Mlati (8\%), Depok (33\%), Berbah (2\%), Kalasan (1\%), Ngemplak (2\%), Ngaglik (35\%), Sleman (8\%), Tempel (2\%), Turi (1\%) dan Pakem $(1 \%)$.

\section{Regresi Linear Berganda}

Analisis regresi linier berganda merupakan modal regresi berganda sederhana yang dikembangkan untuk menaksir nilai variabel dependen dengan menggunakan lebih dari satu variabel independen. Variabel independen yang digunakan dalam penelitian ini ada 5, yakni: manfaat, risiko, motivasi hedonis, faktor psikhologis dan desain situs dan terhadap perilaku belanja online sebagai variabel dependen. Berdasar tabel 1 diperoleh persamaan sebagai berikut:

$$
\mathrm{Y}=0,832+0,216 \mathrm{X}_{1}+0,140 \mathrm{X}_{2}+0,209 \mathrm{X}_{3}+0,166 \mathrm{X}_{4}+0,166 \mathrm{X}_{5}+\mathrm{e}
$$

Tabel 1

\section{Hasil Uji Regresi Linear Berganda}

\begin{tabular}{|c|c|c|c|c|c|}
\hline \multicolumn{6}{|c|}{ Coefficients $^{\mathrm{a}}$} \\
\hline \multirow[t]{3}{*}{ Model } & \multirow{2}{*}{\multicolumn{2}{|c|}{$\begin{array}{l}\text { Unstandardized } \\
\text { Coefficients }\end{array}$}} & \multirow{3}{*}{$\begin{array}{c}\text { Standardized } \\
\text { Coefficients }\end{array}$} & \multirow[t]{3}{*}{$\mathrm{T}$} & \multirow[t]{3}{*}{ Sig. } \\
\hline & & & & & \\
\hline & B & Std. Error & & & \\
\hline (Constant) & ,832 & 2,560 & & ,325 & ,746 \\
\hline Manfaat & ,216 &, 072 & ,242 & 2,992 & ,003 \\
\hline Resiko &, 140 & ,069 & , 167 & 2,044 & ,043 \\
\hline Motivasi Hedonis & ,209 & ,082 & ,210 & 2,559 & ,012 \\
\hline Faktor Psikologis & , 166 & ,077 & , 176 & 2,145 & ,034 \\
\hline Desain Situs & , 166 & ,081 & , 163 & 2,040 & ,043 \\
\hline
\end{tabular}

Sumber: Data primer setelah diolah, 2017

Berdasarkan persamaan tersebut, maka dapat dijelaskan sebagai berikut:

a.Nilai konstanta sebesar 0,832 : artinya jika tanpa manfaat, risiko, motivasi hedonis, faktor psikologis, desain situs, maka nilainya perilaku belanja online sebesar 0,832 satuan.

b.Koefisien regresi manfaat sebesar 0,216, artinya variabel manfaat berpengaruh positif terhadap perilaku konsumen belanja online mahasiswa yang berdomisili di Sleman, jika manfaat mengalami kenaikan 1 satuan dan variabel lainnya tetap, maka perilaku belanja online mengalami peningkatan sebesar 0,216 satuan.

c. Koefisien regresi risiko sebesar 0,140, artinya variabel risiko berpengaruh positif terhadap perilaku belanja online mahasiswa yang berdomisili di Sleman, jika risiko mengalami kenaikan 1 satuan 
dan variabel lainnya tetap, maka perilaku belanja online mengalami peningkatan sebesar 0,140 satuan.

d.Koefisien regresi motivasi hedonis sebesar 0,209, artinya variabel motivasi hedonis berpengaruh positif terhadap perilaku belanja online mahasiswa yang berdomisili di Sleman, jika motivasi hedonis mengalami kenaikan 1 satuan dan variabel lainnya tetap, maka perilaku belanja online mengalami peningkatan sebesar 0,209 satuan.

e.Koefisien regresi faktor psikhologi sebesar 0,166, artinya variabel faktor psikhologi berpengaruh positif terhadap perilaku belanja online mahasiswa yang berdomisili di Sleman, jika faktor psikhologi mengalami kenaikan 1 satuan dan variabel lainnya tetap, maka perilaku belanja online mengalami peningkatan sebesar 0,166 satuan.

f. Koefisien regresi desain situs sebesar 0,166, artinya variabel desain situs berpengaruh positif terhadap perilaku belanja online belanja online mahasiswa yang berdomisili di Sleman, jika desain situs mengalami kenaikan 1 satuan dan variabel lainnya tetap, maka perilaku belanja online mengalami peningkatan sebesar 0,166 satuan

\section{Uji t}

Menurut Wiyono (2011) uji t atau uji parsial dilakukan untuk mengetahui masing-masing variabel independen mempunyai pengaruh atau tidak terhadap variabel dependen dan selanjutnya dapat diketahui variabel independen yang dominan berpengaruh terhadap variabel dependen dengan $\alpha=0.05$ pada tingkat kepercayaan 95\%. Berdasar table 1 diketemukan bahwa:

a. Variabel manfaat memiliki nilai signifikansi 0,003 lebih kecil dari $\alpha$ yang dipakai dalam penelitian ini. Dengan demikian dapat dikatakan bahwa manfaat berpengaruh signifikan terhadap perilaku konsumen belanja online pada mahasiswa yang berdomisili di Sleman.

b. Variabel risiko memiliki nilai signifikansi 0,043 lebih kecil dari $\alpha$ yang dipakai dalam penelitian ini. Dengan demikian dapat dikatakan bahwa risiko berpengaruh signifikan terhadap perilaku konsumen belanja online pada mahasiswa yang berdomisili di Sleman.

c. Variabel motivasi hedonis memiliki nilai signifikansi 0,012 lebih kecil dari $\alpha$ yang dipakai dalam penelitian ini. Dengan demikian dapat dikatakan bahwa motivasi hedonis berpengaruh signifikan terhadap perilaku konsumen belanja online pada mahasiswa yang berdomisili di Sleman.

d. Variabel faktor psikhologi memiliki nilai signifikansi 0,034 lebih kecil dari $\alpha$ yang dipakai dalam penelitian ini. Dengan demikian dapat dikatakan bahwa faktor psikhologi berpengaruh signifikan terhadap perilaku konsumen belanja online pada mahasiswa yang berdomisili di Sleman.

e. Variabel desain situs memiliki nilai signifikansi 0,043 lebih kecil dari $\alpha$ yang dipakai dalam penelitian ini. Dengan demikian dapat dikatakan bahwa desain situs berpengaruh signifikan terhadap perilaku konsumen belanja online pada mahasiswa yang berdomisili di Sleman.

\section{Uji F}

Uji F atau uji serentak yaitu uji yang digunakan untuk melihat bagaimanakah pengaruh seluruh variabel independen secara simultan atau bersama-sama terhadap variabel dependen. (Wiyono, 2011) Hasil uji F dengan $\alpha=0.05$ ditampilkan pada tabel 2 berikut:

\section{Table 2}

\section{Hasil Uji F}

\begin{tabular}{lrrrrrr}
\multicolumn{8}{c}{ ANOVA $^{\mathbf{a}}$} \\
\hline Model & Sum of Squares & Df & $\begin{array}{c}\text { Mean } \\
\text { Square }\end{array}$ & F & Sig. & \\
\hline & & & & & \\
& Regression & 97,397 & 5 & 19,479 & 9,127 & \\
1 & Residual & 264,634 & 124 & 2,134 & & \\
& Total & 362,031 & 129 & & & \\
\hline
\end{tabular}

a. Dependent Variable: Perilaku Konsumen

b. Predictors: (Constant), Desain Situs, Motivasi Hedonis, Manfaat, Resiko, Faktor

Psikologis

Sumber: Data primer setelah diolah, 2017 
Berdasarkan tabel 2 diperoleh nilai signifikansi 0,000, lebih kecil dari $\alpha$ yang dipakai dalam penelitian ini. Dengan demikian dapat dikatakan bahwa manfaat, risiko, motivasi hedonis, faktor psikologis, dan desain situs berpengaruh secara signifikan terhadap perilaku belanja online pada mahasiswa yang berdomisili di Sleman.

\section{Koefisien Determinasi}

Hasil uji koefisien determinasi pada penelitian ini ditampilkan pada tabel 3 berikut ini:

Table 3 Koefisien Determinasi

\begin{tabular}{|c|c|c|c|c|}
\hline \multicolumn{5}{|c|}{ Model Summary } \\
\hline Model & $\mathrm{R}$ & R Square & $\begin{array}{c}\text { Adjusted R } \\
\text { Square }\end{array}$ & $\begin{array}{c}\text { Std. Error of the } \\
\text { Estimate }\end{array}$ \\
\hline 1 &, $519^{\mathrm{a}}$ & ,269 & ,240 & 1,46087 \\
\hline
\end{tabular}

Sumber: Data priimer setelah diolah, 2017

Berdasarkan tabel 3 di atas, diperoleh nilai adjusted $R$ Square sebesar 0,240 (24\%). Hal ini berarti bahwa $24 \%$ variabel dependen perilaku belanja online dijelaskan oleh variabel manfaat, risiko, motivasi hedonis, dan desain situs sisanya sebesar $76 \%$ dijelaskan oleh variabel lain yang tidak termasuk dalam penelitian ini.

\section{Pembahasan}

Dari semua uji yang dilakukan dengan menggunakan SPSS 19,00 for Windows, bahwa semua hipotesis dapat diterima. Hipotesis pertama yang menyatakan bahwa manfaat berpengaruh positif terhadap perilaku belanja online mahasiswa yang berdomisili di Kabupaten Sleman diterima. Temuan ini sangat logis karena mahasiswa sebagai konsumen selalu ingin mendapatkan manfaat dengan melakukan belanja online. Manfaat yang dimaksud adalah sesuai dengan yang dijelaskan oleh Forsythe et al., (2006).

Dengan demikian makin banyak manfaat yang diperoleh maka makin sering mahasiswa melakukan belanja online. Hal ini sejalan dengan penelitian yang dilakukan oleh Prihandy dan Hattamimii (2015) dengan subyek konsumen umum di wilayah JABODETABEK, yang menyatakan bahwa variabel manfaat berpengaruh signifikan terhadap perilaku belanja online. Temuan yang sama dilakukan oleh Hsu dan Bayarsaikhan (2012) dengan subyek para konsumer online store yang diambil secara random dari www.tedy.mn online store in Mongolian menyatakan bahwa manfaat sangat menentukan perilaku belanja online.

Hipotesis kedua yang menyatakan bahwa risiko berpengaruh positif terhadap perilaku belanja online mahasiswa yang berdomisili di Kabupaten Sleman diterima. Hal ini bisa terjadi karena dalam penelitian ini mahasiswa mempersepsikan risiko yang mereka hadapi dilindungi karena selama melakukan belanja online tidak atau belum pernah menghadapi hal yang tak menyenangkan. Hal ini sejalan dengan penelitian yang dilakukan oleh Prihandy dan Hattamimii (2015) dengan subyek konsumen umum di wilayah JABODETABEK, yang menyatakan bahwa variabel manfaat berpengaruh signifikan terhadap perilaku belanja online.Temuan yang sama dilakukan Wani dan Malik (2013) dengan subyek para shoppers dari India dan United Kingdom (UK) dengan kriteria mereka telah memakai internet selama lebih dari 5 tahun. Hasilnya menyatakan bahwa risiko berpe ngaruh terhadap perilaku belanja online namun berbeda antara shoppers India dan UK. Namun penelitian yang dilakukan Forsythe et all, (2006) mengidentifikasi risiko terkait dengan kinerja produk dan waktu yang hilang dalam proses pembelian dan penerimaan produk merupakan faktor penghalang utama keinginan untuk melakukan belanja online.

Hipotesis ketiga yang menyatakan bahwa motivasi hedonis berpengaruh positif terhadap perilaku belanja online mahasiswa yang berdomisili di Kabupaten Sleman diterima. Temuan ini sangat logis karena mahasiswa sebagai konsumen melihat belanja sebagai alat untuk mencari kesenangan, fantasi, kegembiraan, dan pengalaman yang menyenangkan baik dalam lingkungan belanja offline maupun 
online (Lai To dan Sung, 2014). Lingkungan belanja online yang demikian akan meningkatkan keinginan untuk melakukan belanja online. Hal ini sejalan dengan penelitian yang dilakukan oleh Prihandy dan Hattamimii (2015) dengan subyek konsumen umum di wilayah JABODETABEK, yang menyatakan bahwa variabel manfaat berpengaruh signifikan terhadap perilaku belanja online. Penelitian yang dilakukan oleh Lai-To dan Sung (2014) menemukan bahwa motivasi hedonis menentukan perilaku belanja online berarti besarnya dorongan hedonisme akan mendorong mahasiswa melakukan belanja online.

Hipotesis keempat yang menyatakan bahwa faktor psikhologis berpengaruh positif terhadap perilaku belanja online mahasiswa yang berdomisili di Kabupaten Sleman diterima. Hal ini bisa terjadi karena dalam penelitian ini faktor psikhologis yang mereka rasakan selama melakukan belanja online tidak atau belum pernah menghadapi hal yang tak menyenangkan. Hal ini sejalan dengan penelitian yang dilakukan oleh Prihandy dan Hattamimii (2015) dengan subyek konsumen umum di wilayah JABODETABEK, yang menyatakan bahwa variabel faktor psikhologis berpengaruh signifikan terhadap perilaku belanja online. Studi Yörük et al (2011) faktor psikhologis yang terdiri dari kepercayaan dan keamanan merupakan faktor penghalang utama bagi konsumen melakukan belanja online. Menurut penelitian Monsuwe et al (2004) retailer yang menjaga kepercayaan dan keamanan informasi personal memberi dorongan positif shopper untuk melakukan belanja online.

Hipotesis kelima yang menyatakan bahwa desain situs berpengaruh positif terhadap perilaku belanja online mahasiswa yang berdomisili di Kabupaten Sleman diterima. Temuan ini sangat logis karena mahasiswa sebagai konsumen jika melakukan belanja online maka selalu melihat situs. Dengan demikian kualitas desain situs menjadi hal yang krusial bagi retailer belanja online. Kualitas desain situs yang tinggi membuat shoppers lebih nyaman dalam melakukan belanja online. Hal ini sejalan dengan penelitian yang dilakukan oleh Prihandy dan Hattamimii (2015) dengan subyek konsumen umum di wilayah JABODETABEK, yang menyatakan bahwa variabel desain situs berpengaruh signifikan terhadap perilaku belanja online. Penelitian yang dilakukan Suwunniponth (2014) menyatakan bahwa desain situs berpengaruh terhadap perilaku belanja online konsumen di Bangkok.

Secara bersama-sama kelima variabel independen dalam penelitian ini berpengaruh terhadap perilaku belanja online $\left(\mathrm{H}_{6}\right.$ diterima) meskipun hanya $24 \%$. Dengan demikian dapat dikatakan bahwa terhadap perilaku belanja online mahasiswa yang berdomisili di Kabupaten Sleman tidak begitu dipengaruhi oleh variabel manfaat, risiko, motivasi hedonis, faktor psikhologis dan desain situs. Masih terdapat sejumlah variabel lain yang memiliki pengaruh lebih besar terhadap terhadap perilaku belanja online mahasiswa yang berdomisili di Kabupaten Sleman.

\section{PENUTUP \\ Kesimpulan}

Berdasarkan analisis dan pembahasan yang telah dilakukan maka dapat diambil kesimpulan sebagai berikut:

1. Manfaat berpengaruh positif dan signifikan terhadap perilaku belanja online mahasiswa yang berdomisili di Kabupaten Sleman, hal ini ditunjukkan oleh koefisien regresi sebesar 0,216 dengan nilai signifikansi 0,003. Dengan demikian $\mathrm{H}_{1}$ diterima.

2. Risiko berpengaruh positif dan signifikan terhadap perilaku belanja online mahasiswa yang berdomisili di Kabupaten Sleman, hal ini ditunjukkan oleh koefisien regresi sebesar 0,140 dengan nilai signifikansi 0,043. Dengan demikian $\mathrm{H}_{2}$ diterima.

3. Motivasi hedonis berpengaruh positif dan signifikan terhadap perilaku belanja online mahasiswa yang berdomisili di Kabupaten Sleman, hal ini ditunjukkan oleh koefisien regresi sebesar 0,209 dengan nilai signifikansi 0,012. Dengan demikian $\mathrm{H}_{3}$ diterima.

4. Faktor psikologis berpengaruh positif dan signifikan terhadap perilaku belanja online mahasiswa yang berdomisili di Kabupaten Sleman, hal ini ditunjukkan oleh koefisien regresi sebesar 0,166 dengan nilai signifikansi 0,034. Dengan demikian $\mathrm{H}_{4}$ diterima.

5. Desain situs berpengaruh positif dan signifikan terhadap perilaku belanja online mahasiswa yang berdomisili di Kabupaten Sleman, hal ini ditunjukkan oleh koefisien regresi sebesar 0,166 dengan nilai signifikansi 0,043. Dengan demikian $\mathrm{H}_{5}$ diterima.

6. Manfaat, risiko, motivasi hedonis, faktor psikologis, dan desain situs secara simultan berpengaruh signifikan terhadap perilaku belanja online pada mahasiswa yang berdomisili di Sleman, hal ini ditunjukkan oleh hasil Uji F pada tabel ANOFA $^{\text {a }}$ dengan nilai signifikasi 0,000 dengan demikian $\mathrm{H}_{6}$ diterima. 


\section{Saran}

Dari hasil analisis dan kesimpulan yang telah diuraikan, maka saran yang dapat disampaikan sebagai berikut:

1. Membuat sebuah sistem pemesanan dan pembayaran yang terintegrasi baik dengan seluruh alat pembayaran secara online maupun konvensional agar dapat menjangkau seluruh konsumen.

2. Membuat sistem pengiriman yang tidak dibatasi dengan waktu dan lokasi dari konsumen. Memberikan layanan pengiriman 24 jam dan dimanapun konsumen berada, menjadi sebuah masa depan bagi perkembangan belanja online.

3. Membuat sebuah desain dan fitur situs yang menarik serta mudah digunakan konsumen. Desain yang menarik pada situs belanja online dengan tidak mengurangi kemudahan dalam menggunakannya akan membuat konsumen tidak jenuh dalam melakukan kegiatan belanja online.

4. Membuat sebuah prosedur yang tepat dan baik untuk menjaga kepercayaan serta privasi konsumen. Karena melindungi informasi pribadi konsumen, akan meningkatkan kepercayaan dari konsumen itu sendiri. Namun bukan berarti pelaku bisnis toko online tidak meminta identitas konsumen secara lengkap ketika proses belanja online konsumen hanya tidak menginginkan informasi pribadi mereka disalahgunakan.

5. Bagi peneliti selanjutnya yang akan melakukan penelitian yang sama hendaknya menambahkan variabel independen lain yang diduga akan berpengaruh pada laku belanja online mahasiswa misal personalitas, risiko dipecah menjadi beberapa jenis risiko seperti financial, kinerja produk, pengiriman, keamanan dan kepercayaan, demografi. Hal ini didasarkan pada tenuan bahwa manfaat, risiko, motivasi hedonis, faktor psikologis, dan desain situs secara simultan berpengaruh hanya sebesar $24 \%$ dan sisanya sebesar $76 \%$ perilaku belanja online dipengaruhi variabel lain.

\section{DAFTAR PUSTAKA}

Abdullah, Thamrin dan Francis Tantri. 2012. Manajemen Pemasaran. Depok: PT Raja Grafindo Persada.

Adnan, Hooria. 2014. An Analysis of the Factors Affecting Online Purchasing Behavior of Pakistani Consumers - Lahore School Of Economics. International Journal of Marketing Studies. Canadian Center of Science and Education. 6(5), 133-149.

Ali, Maskur. 2010. Pengertian Internet dan Sejarah Internet. Yogyakarta: Kanisius.

Ariff, M.S.M., Yan, N.S., Zakuan, N., Bahari, A.Z., Jusoh, A., 2013. Web Based Factors Affecting Online Purchasing Behavior. IOP Conf. Series: Materials Science and Engineering, Vol. 47, 1-10.

Batra, R and O.T. Ahtola. 1991, Measuring th Hedonic and Utilitarian Sources of Consumer Attitudes. Marketing letters, 2(2) 159-170

Bhatnagar, A., Misra, S., \& Rao, H.R. On Risk, Convenienceand Internet Shopping Behavior. Communications of the ACM, 48(2) , 98-105. http://dx.doi.org/10.1145/353360.353371

Chen, Y. H., Hsu, I., \& Lin, C. C. 2010. Website attributes that increase consumer purchase intention: A conjoint analysis. Journal of business research. 63(9), 1007-1014.

Childers, T.L., Carr, C.L., Peck, J., Carson, S., 2001. Hedonic an Utilitarian Motivations for Online Retal Shopping Behavior. Journal of Retailing. 77(4) 511-535.

Close, A. G., \& Kukar-Kinney, M. 2010. Beyond buying: Motivations behind consumers' online shopping cart use. Journal of Business Research 63(9), 986-992.

Delafrooz, N., Pain, L.H., Khatibi, A., 2010. Students, online Shopping Behavior: An Empirical Study. Journal of American Science. 6(1), 137-147.

Ebert, R.J., and Griffin, R.W., 2017. Business Essential, 11 ${ }^{\text {th }}$ edition, Harlow Essex, Pearson Education Limited. 
Forsythe,S., Liu, C. Shannon, D \& Gardner, L, 2006, Development of Scale to Measure the Perceived Benefits and Risks of Online Shopping. Journal of Interactive Marketing. 20(2), 55-75.

Ghozali, Imam, 2013. Aplikasi Analisis Multivariat dengan Program IBM SPSS 21. Edisi 7, Semarang: Penerbit Universitas Diponegoro.

Goenawan, Muhammad Alif. 2015. Omset Lapak Online Diprediksi 'Cuma' Rp 224 Triliun. inet.detik.com/cyberlife/d-3090969/omset-lapak-online-diprediksi-cuma-rp-224-triliun, diakses tanggal 12 Februari 2016.

Hsu, Shu Hung and Bayarsaikhan, Bat Erdene. 2012, Factors Inflence on Online Shopping Attitude and Intention of Mongolian Consumers. The Journal of International Management Studies, 7(2) , 167176.

Javadi, M. H. M. , Dolatabadi, H. R., Nourbakhsh, M., Poursaeedi, A., \& Asadollahi, A. R. (2012). An Analysis of Factors Affecting on Online Shopping Behavior of Consumers. International Journal of Marketing Studies. Canadian Center of Science and Education. 4(6), 81-98.

Jones Lang Lasalle IP. Inc. 2013. Global E-Commerce and Retail Logistics.

Khanh, Ngo Tan Vu ., Gim, Gwangyong. 2014. Factors Affecting the Online Shopping Behavior: An Empirical Investigation in Vietnam. International Journal of Engineering Research and Application, Vol. 4 Issue 2 (Version1). 388-393.

Khasali Renald, 2017. Disruption, Tak Ada Yang Tak Bisa Diubah Sebelum Dihadapi Motivasi Saja Tidak Cukup, Cetakan Pertama, Jakarta: Gramedia Pustaka Utama.

Kim, J., Lee, H. C., \& Kim, H. J. 2004. Factors Affecting Online Search Intention and Online Purchase Intention. Seoul, Journal of Business. 10(2), 27-48.

Kotler, Philip dan Gary Armstrong. 2012. Prinsip-prinsip Pemasaran. Edisi. 13. Jilid 1. Jakarta: Erlangga.

Lai to, Pui and Sung, E-Ping. 2014. Hedonic Motivations for Online Shopping. International Journal of Socia, Behavioral, Educational, Economics, Business and Industrial Engineering., 8(7), 22222224

Lee, H. J., \& Huddleston, P. T. 2010. An investigation of the relationships among domain-specific innovativeness, overall perceived risk and online purchase behavior. International Journal of Electronic Marketing and Retailing, 3(1), 1-4.

Lee, D., Park, J., Ahn, J., 2001. On the explanation of factors affecting e-commerce adoption, Proceedings of the 22nd International Conference on Information Systems, 109-120.

Li,Na ., Zhang, Ping. 2002. Consumer online Shopping Attitudes and Behavior: An Assessment of Research. Eighth America Conference on Information Systems, 508-517.

McGuigan, Brendan. 2003.wiseGEEK: What is eBusiness?. Conjecture Corporation. wisegeek.org/what-is-ebusiness.htm, diakses tanggal 10 Februari 2016.

Monsuwé, T.P.Y., Dellaert, B.G.C., Ruyter, K.D. 2004. What Drives Consumer to shop Online? A Literature review. International Journal of Service Industry Management. 15(1). 102-121

Olsen, R. (2010). China's migration to e-Commerce. Forbes.com. forbes.com/2010/01/18/china-internetcommerce-markets-equities-alibaba.html, diakses tanggal 9 Februari 2016. 
Pratiwi, Haning Dwi. 2013. Online Shop Sebagai Cara Belanja Di Kalangan Mahasiswa UNNES. Skripsi. Universitas Negeri Semarang.

Prihandy, Aditya., \& Hatammimi, Jurry. 2014. Influence of Perceived Benefits, Perceived Risks, Psychological Factors, Hedonic Motivations, and Web Design to Online Shopping Behavior JABODETABEK in 2014. Skripsi. Universitas TELKOM. Bandung.

Rehman, A. (2000). Holiday 2000 E-commerce. Unpublished report, Creative Good, New York, NY.

Robinson, J. 2010. UK's internet industry worth 1 100bn-report. The Guardian. theguardian.com/technology/2010/oct/28/net-worth-100bn-uk, diakses tanggal 11 Februari 2016.

Román, S. 2007. The Ethics of Online retailing: A Scale Development and Validation from Consumers' Perspective. Journal of Business Ethics. 72(2). 131-148

Shahzad, Hashim, 2015, Online Shopping Behavior, Thesis, UUPSALA UNIVERSITET.

Schaupp, L. C., \& Bélanger, F. 2005. A conjoint analysis of online consumer satisfaction. Journal of Electronic Commerce Research. 6(2), 95-111.

Soopramanien, D. G. R., \& Robertson, A. 2007. An empirical analysis of the characteristics of buyers browsers and non-internet shoppers. Journal of Retailing and Consumer Services. 14(1), 73-82.

Sugiyono, 2013. Metode Penelitian Manajemen. Bandung: Alfabeta.

Suhari, Yohanes. 2011, E-commerce : Model Perilaku Konsumen, academia.edu/7491785/ecommerce model_perilaku_konsumen, diakses tanggal 12 Februari 2016.

Sutabri, Tata. 2012. Konsep Sistem Informasi. Yogyakarta: Andi.

Suwunnipoth, W. 2014. Factor Driving Consumer Intention in Online Shopping . International Journal of Social, Education, Economicsand Management Engineering. 8(6). 1927-1931

Suyanto, M. 2003. E-commerce Perusahaan Top Dunia. Yogyakarta: Andi.

Titchener, E.B. 1921. Brentano and Wundt: Empirical and Experimental Psychology. American Journal of Psychology. 32(2), 108-120.

Wani, S,N., Malik, S., 2013. A Comparative Study of Online Shopping Behavior: Effects of Perceived Risks and Benefits, International Journal of Marketing and Business Communication. 4(2), 41-55.

Wiyono, Gendro. 2011. Merancang Penelitian Bisnis. Yogyakarta: UPP STIM YKPN.

Wong, Jony, 2010, Internet Marketing for Beginners, Jakarta: Elex Media Komputindo.

Yörük, D., Dündar, S., Moga, L.M., Neculita, M. 2011. Drivers and Attitudes Towards Online Shopping: Comparison of Turkey with Romania. BIMA Publishing, Communication of the IBIMA. Vol 2011. 1-13.

Kearney, A. T. (2001). Satisfying the experienced on-line shopper. Global E-Shopping Survey. atkearney.com/ Satisfying-the-experienced -on-line-shopper.htm, diakses tanggal 10 Februari 2016. 